\title{
Plastik Şekil Değişimine Uğramış Otomobil Rotunun Yorulma Davranışının Deneysel ve Sayısal Analizi
}

\section{Experimental and Numerical Fatigue Behavior Analysis of a Plastically Deformed Automobile Tie Rod}

\author{
Ișın Naz Budak ${ }^{1}$ (1) Mahmut Pekedis $^{2 *}$ \\ ${ }^{1}$ Lemförder Aks Modülleri A.Ș, İzmir, TÜRKIYE \\ ${ }^{2}$ Ege Üniversitesi, Mühendislik Fakültesi, Makine Mühendisliği Bölümü, İzmir, TÜRKIYE \\ Sorumlu Yazar / Corresponding Author*: mahmut.pekedis@ege.edu.tr
}

$\ddot{0} \mathbf{z}$

Otomobil rotu genellikle daha önce hiçbir kuvvet etkisi altında kalmamış ve üzerinde hiçbir kalıcı şekil değişimi meydana gelmemiş kabul edilerek test ve analiz edilmektedir; ancak rot, araçta birçok kuvvete maruz kalmaktadır ve bu kuvvetler rot başında plastik şekil değişimine neden olabilir. Rot başı, aracın sürüş stabilitesini bozmayan bir değerde deforme olduğunda sürücü bunu fark edemeyebilir ve aracı kullanmaya devam edebilir. Bunun sonucunda ön deformasyona uğramıș olan rot başına sürüş sırasında tekrarlı kuvvetler uygulandığında yorulma ömrü bu ön deformasyondan etkilenebilir. Rot başı, tahmin edilen ömürden daha kısa bir sürede yorulma hasarı alarak sürüş güvenliğini tehlikeye atabilir. Çalışma kapsamında binek araç rot başı tasarımı için önemli bir kriter olan yorulma dayanımı, hem hiçbir ön deformasyona maruz kalmamış standart rot başlarında hem de parça üzerinde plastik şekil değişimi meydana getiren bir ön yükleme ile deformasyona uğratılmış rot başlarında araştırılmıştır. Öncelikle, rot başına uygulanacak olan ön yükleme belirlenmiştir. Sonra, hem sağlıklı hem de ön deformasyona uğramış rotlar için yorulma testleri ve sonlu elemanlar analizleri gerçekleştirilmiştir. Analiz sonuçları, Bergmann, Morrow ve SmithWatson-Topper adlı yorulma modellerinde işlenerek uygulanan yaklaşımın hassasiyeti belirlenmiștir. En sonunda, ön deformasyonun yorulma ömrüne olan etkisi deneysel ve sayısal olarak araştırılıp elde edilen sonuçlar birbirleriyle karşılaștırılmıştır. Sonuçlar, ön deformasyonun rot başı yorulma ömrünü kayda değer bir șekilde etkilediği ve bunun tasarım sürecinde dikkate alınması gerektiğini göstermiştir.

Anahtar Kelimeler: Rot, Rot başı, Yorulma ömrü tahmini, Ön deformasyon, Nümerik analiz, Yorulma modelleri

\begin{abstract}
Automobile tie rod is generally tested and analyzed by assuming that it has never been previously subjected to any load and no permanent deformation has occurred on it. However, the tie rod is subjected to various forces while driving and these forces can cause plastic deformation at the tie rod end. If tie rod is deformed to a value that does not affect the driving stability of the vehicle, the driver may not be able to detect it and continue driving. As a result, fatigue life can be influenced by this pre-deformation if repeated forces are applied to tie rod, which has undergone predeformation, during driving. The tie rod end can endanger the driving safety by causing fatigue damage earlier than the estimated life. In this study, fatigue strength, which is an important
\end{abstract}


criterion for the design of passenger car tie rod end is investigated both on standard tie rod ends which were not pre-deformed and on tie rod ends which were deformed with a preload that caused plastic deformation on the part. Initially, the preload to be applied on the tie rod is determined. Then fatigue tests and the finite element analyses are performed for both healthy and pre-deformed rods. The sensitivity of the approach is determined by processing the analysis results in fatigue models such as Bergmann, Morrow and Smith-Watson-Topper. Finally, the effect of pre-deformation on fatigue life is explored both experimentally and numerically and the results are compared with each other. The results have shown that pre-deformation significantly affects the fatigue life of the tie rod end which should be considered at design step.

Keywords:Rod, Tie rod end, Fatigue life estimation, Pre-deformation, Numerical analysis, Fatigue models

\section{Giriş}

Otomotiv sektöründe artan rekabet ile birlikte daha hızlı ve maliyeti az olan tasarım doğrulama yöntemlerine ihtiyaç duyulmaktadır. Yol verilerinin kullanımı, analiz yöntemleri gibi gelişmiş teknikler bu ihtiyaç doğrultusunda günümüzde yaygın olarak kullanılmaktadır. Binek araçların, yakıt tasarrufu, konfor, dayanım ve güvenlik unsurlarını sağlaması beklenmektedir. Araçta parçaların statik olarak dayanımları yüksek olsa dahi, tekrarlı yüklere maruz kaldıklarında akma dayanımının altındaki gerilme değerlerinde hasara uğrayabilmektedirler. Bu tekrarlı yükler altında parçanın hasara uğramasına "yorulma" adı verilir[1]. Yorulma kaynaklı hasar ani gerçekleștiğinden bunun önceden belirlenmesi büyük önem arz etmektedir. Gerçek kullanım șartlarında, yorulma hasarları uzun süreler sonucunda oluşmaktadır. $\mathrm{Bu}$ nedenle yorulmadan kaynaklanan hasarın kısa bir sürede belirlenebilmesi zordur. Yorulma dayanımı test süreleri parçanın tasarım onay sürecindeki diğer testlere oranla daha uzun sürede gerçekleșmektedir. Günümüzde artan teknolojik gelişmeler ile birlikte Bilgisayar Destekli Mühendislik (BDM) uygulamaları, parça ömrünün belirlenmesinde önemli rol oynamaktadır. $\mathrm{Bu}$ sanal ortamda gerçekleștirilen analizler sayesinde süre ve maliyet avantajı elde edilmektedir. Kabuller ile gerçekleştirilen sonlu elemanlar analizlerinin doğruluk oranını yükseltebilmek için test ile analiz arasında bir korelasyonun sağlanması gerekmektedir. Bu şekilde Bilgisayar Destekli Mühendislik uygulamaları ile birlikte ürün geliştirme süreci büyük ölçüde kısalmıştır.

Binek araç, birçok farklı yol koşullarında değișken ve tekrarlı yüklere maruz kalmaktadır. Yorulma ömrü, bu nedenle binek araçlarda çok önemli bir tasarım kriteri olmaktadır. Otomotiv ve uçak sanayide meydana gelen hasarlar incelendiğinde, yorulmadan kaynaklanan hasarların toplam hasarların \%80-90 civarını oluşturmaktadır. Parçaların fonksiyonunu koruyarak belirli bir ömür boyunca sorunsuz bir şekilde kullanılabilecek dayanımda olması gerekmektedir. Parçada yorulma hasarı üç aşamada gerçekleşir; çatlak başlangıcl, çatlak ilerlemesi ve yorulma kırılması. Yorulma tipik olarak düşük çevrim ( $<1000$ çevrim) ve yüksek çevrim (>1000 çevrim) olarak karakterize edilir. Düşük ve yüksek çevrimi birbirinden ayıran çevrim değeri kesin olmamakla beraber bir kabuldür [2].

Binek araçlarda, direksiyon ve süspansiyon sistemi elemanları şasi ve tekerlekler arasında bir bağlantı sağlamakta ve taşıtın dinamik ve statik yüklerini taşımaktadır. Yorulma bu sistem elemanlarında önemli bir kriterdir [3],[4]. Yorulma dayanımının tayin edilebilmesi için birkaç yöntem mevcuttur; aracın yol üzerinde sürülmesi ile yapılan testler, hızlandırılmış test pistlerinde yapilan testler, laboratuvarlarda yapılan testler ve BDM araçları ile yapılan yorulma ömür tahminleri [5]. Bunlar içinde testler maliyeti ve uzun zaman gerektirdiği için sanal doğrulama araçlarına nazaran dezavantajlıdır. Bilgisayar Destekli Mühendislik araçlarının kullanımının ve doğruluğunun artması ile birlikte tasarımlar prototip için üretilmeden kontrol edilebilmekte ve istenilen değerleri sağlayıp sağlayamadığı önceden bilinebilmektedir.

Bir araç hız rampası, bozuk yollar ve çukurlar üzerinden geçerken yatay, dikey ve yanal kuvvetlere maruz kaldığında, bu kuvvetler süspansiyon sistemi üzerinden rotun da içinde bulunduğu diğer parçalara aktarılır. Rot bu koşullarda bası veya çeki kuvveti altındadır. 
Sonuç olarak rot bașı bu kuvvetler altında hasara uğrayabilir, tekerleklerin açılarını bozarak yanlıs hizalanmasına neden olabilir ve sürücü ve yolcuların hayatını tehlikeye atabilir[6],[7]. Binek araç rotu, güvenlik açısından önemli bir parçadır, hasar aldığı takdirde can ve mal kaybına neden olabilir. Bu nedenle, tasarımında gerekli önemin gösterilmesi gerekmektedir. Rot, çukur ve çok fazla hız rampası gibi kötü yol şartlarında üzerine etkiyen bası kuvvetinden ötürü burkulabilir. Aynı zamanda çalıșma sürecinde birçok tekrarlı yüke maruz kalması nedeniyle bu yükler altında yorulma kırılması meydana gelebilir.

Araç düz bir yolda seyir halindeyken daha düșük genlikli gerilmeler altındadır. Pürüzlü bir yolda ilerlerken, viraj alırken ve çukurlar ya da hız rampaları ile karakterize edilmiș yol gibi sık rastlanmayan yol yüzeylerinde ilerlerken rota gelen kuvvetler artmaktadır ve bu tasarım aşamasında dikkat edilmesi gereken önemli bir husustur. Rot, ivmelenme, frenleme, viraj alma gibi durumlarda oluşan kuvvetleri hasar almadan taşıyacak şekilde tasarlanmalıdır. Sürüş esnasında birçok yük senaryosu meydana gelmektedir. Bunlar süspansiyon sistemine etki etmekte ve rotun da içinde bulunduğu diğer parçalara aktarılmaktadır.

Rot başları gerek yorulma simülasyonu gerekse dayanım testlerinde genellikle daha önce hiçbir yük altında kalmamıș bir şekilde analiz ve test edilirler; ancak gerçek durumda rot başları kullanımı esnasında standart olmayan yükler altında plastik deformasyona uğrayabilirler ve bu rot bașının ömrünü etkileyebilecek bir değişimdir. Literatürde, plastik deformasyona maruz kalmış rotların yorulma davranışını inceleyen herhangi bir araștırmaya bilgi dâhilinde rastlanmamıştır. Ancak kompozit yapılar [8], beton köprü[9] ve kirişler[10]için rapor edilen çalıșmalarda ön gerilmenin yorulma ömrünü kayda değer bir şekilde etkilediği belirtilmiştir. Bu çalışmada, ön plastik deformasyonun yorulma davranışına olan etkisi incelenmiștir. $\mathrm{Bu}$ amaçla, incelenen rot, araç stabilitesinin bozulmadığ ve bu nedenle sürücünün binek araç rotunda bir problem hissedemediği maksimum yük ile ön deformasyona uğratılmıștır. Bu yük rot başına etkidiğinde, sürücü rot bașında bir problem meydana geldiğini sürüș stabilitesinden anlayamayabilir ve aracı deforme olmuş rot başı ile kullanmaya devam eder. Sonuçta rot başı öngörülen ömürden daha kısa sürede hasara uğrayabilir. Bu araștırma kapsamında bu durum incelenmiștir. Aynı zamanda rot burkulmaya uğradığında eğer rot kolundan burkulmuş ise rot başında gözle görülür bir deformasyon meydana gelmeyebilir. Bu nedenle rotun sadece rot kolu değiştirilebilir; ancak gerçekte rot başında plastik deformasyon meydana gelmiş olabilir. Sürücü bu deforme olmuş rot başı ile sürüşüne devam ederse, beklenen ömürden daha az bir değerde rot bașında kırılma meydana gelebilir. Rot başının ön deformasyon ile plastik șekil değișimine uğraması ömür açısından önemli görülmüş olup bu çalışma kapsamında incelenmiştir.

$\mathrm{Bu}$ çalıșmanın içeriğinde rot bașı önce ön deformasyona uğratılmış, üzerinde plastik deformasyon meydana gelmiș ve bu deforme olmuş rot başı daha sonra yorulma testine tabi tutulmuştur. Aynı zamanda ön deformasyona uğramamış rot başları da yorulma testine alınarak incelenmiştir. Sonuçta, bu iki durum sonlu elemanlar yöntemi ile analiz edilerek sonuçlar karşılaştırılmıștır. Nümerik ve deneysel sonuçların birbiri ile tutarlılığı kontrol edilmiș ve ön deformasyonun rot üzerindeki etkisi incelenmiştir.

\section{Yorulma Ömür Tahmini}

Malzemede çatlak başlangıcı ve çatlak ilerlemesi, toplam ömrü oluşturur. Bazı malzemelerde çatlak ilerlemesi toplam ömürde fazla bir orana sahipken, bazı malzemelerde ise tam tersi gözlemlenir. Bu çalışmada Morrow, Bergmann ve Smith-Watson-Topper (SWT) olmak üzere 3 farklı yorulma modeli nümerik analizlerde incelenmiștir.

Ortalama gerilme düzeltme modellerinden Morrow[11],

$$
\frac{\sigma_{a}}{\sigma_{a r}}+\frac{\sigma_{m}}{\sigma_{f}}=1
$$

ve Smith-Watson-Topper ise (SWT) [12]

$$
\sigma_{a r}=\sqrt{\sigma_{m} \sigma_{a}}
$$

ile ifade edilip burada, $\sigma_{a}$ gerilme genliğini, $\sigma_{\mathrm{m}}$ ortalama gerilmeyi, $\sigma_{\text {ar }}$ eşdeğer tam tersinir gerilme büyüklügünü ve $\sigma_{f}$ ise kırılma dayanımını ifade etmektedir. 
Yük seviyeleri düșük olduğunda gerilme ve birim șekil değiștirme doğrusal bir orantıya sahiptir. Yüksek yük seviyelerinde, düşük çevrimli yorulma bölgelerinde, malzemenin davranışı en iyi şekil değişimi kontrollü testler ile belirlenmektedir. Yorulma araştırmaları göstermiștir ki hasar ile plastik deformasyon arasında bir bağlantı bulunmaktadır. Birim șekil değiștirme-ömür yönteminde şekil değişimi ölçülmekte ve değeri belirlenmektedir. Buna karşın, gerilme-ömür yönteminde plastik şekil değişimini hesaba katılmamaktadır. Plastik şekil değişiminin göz ardı edilebileceği yüksek ömürlerde gerilme-ömür ve birim şekil değiștirme-ömür yaklaşımları benzerlik gösterir.

Test numunesinin şekil değişimi kontrollü test verilerinden elde edilmiş olan yorulma malzeme özellikleri, kritik bölgedeki gerilmeşekil değiștirme verisi, ortalama gerilme etkisini de içeren yöntemler ve hasar toplama yöntemlerini kullanarak birim şekil değiştirmeömür yöntemi ile yorulma ömür tahminleri yapılabilir [1].

Basquin uzun yıllar önce gerilme ile ömür arasındaki ilișkiyi logaritmik ölçekte doğrusal olarak aşağıdaki gibi ifade etmiştir[13].

$$
\Delta \sigma=\sigma_{\mathrm{f}}^{\prime}\left(2 \mathrm{~N}_{\mathrm{f}}\right)^{\mathrm{b}}
$$

Üsteki denklemde, $\Delta \sigma / 2$ gerçek gerilme genliğini, $\sigma_{\mathrm{f}}$ yorulma direnç sabitini, $\mathrm{N}_{\mathrm{f}}$ yorulma ömrünü ve $b$ ise yorulma dayanım üssünü ifade etmektedir.

Aşağıda verilen Coffin-Manson denkleminde,

$$
\frac{\Delta \varepsilon_{p}}{2}=\varepsilon_{\mathrm{f}}^{\prime}\left(2 \mathrm{~N}_{\mathrm{f}}\right)^{\mathrm{c}}
$$

birim șekil değiştirme-ömür verisinin de logaritmik bir ölçekte doğrusal bir özelliğe sahiptir. Denklemde, $\Delta \varepsilon_{\mathrm{p}} / 2$ plastik şekil değiștirme genliğini, $\varepsilon f^{\prime}$ yorulma süneklik sabitini ve c ise yorulma süneklik üstelini ifade etmektedir.

Birim șekil değiștirme, elastik ve plastik şekil değiştirmelerin toplamına eşit olup,

$$
\frac{\Delta \varepsilon}{2}=\frac{\Delta \varepsilon_{\mathrm{e}}}{2}+\frac{\Delta \varepsilon_{\mathrm{p}}}{2}
$$

olarak ifade edilir. Hooke yasası,

$$
\frac{\Delta \varepsilon_{\mathrm{e}}}{2}=\frac{\Delta \sigma}{2 \mathrm{E}}
$$

șeklinde olup, E elastisite modülüdür. Denklem (3) ve (6)'dan elastik terim ifadesi aşağıdaki gibi yeniden düzenlenebilir.

$$
\frac{\Delta \varepsilon_{e}}{2}=\frac{\sigma_{\mathrm{f}}^{\prime}}{E}\left(2 \mathrm{~N}_{\mathrm{f}}\right)^{\mathrm{b}}
$$

Yorulma ömrüne bağlı olarak toplam birim şekil değișimi,

$$
\frac{\Delta \varepsilon}{2}=\frac{\sigma_{\mathrm{f}}^{\prime}}{E}\left(2 \mathrm{~N}_{\mathrm{f}}\right)^{\mathrm{b}}+\varepsilon_{\mathrm{f}}^{\prime}\left(2 \mathrm{~N}_{\mathrm{f}}\right)^{\mathrm{c}}
$$

şeklinde gösterilebilir.

Elastik ve plastik bağıntılar logaritmik gösterimde doğrusaldır ve toplam șekil değiştirme genliği bu iki verinin toplanmasıyla hesap edilir. Yüksek şekil değiştirme genliklerinde şekil değiştirme-ömür eğrisi plastik doğruya yaklaşırken, düşük genliklerde ise eğri elastik doğruya yaklașır.

Morrow, birim șekil değiștirme ömür denklemindeki elastik terimi değiștirerek ortalama gerilme etkisinin aşağıdaki gibi hesaba katılabileceğini öne sürmüştür[14].

$$
\frac{\Delta \varepsilon}{2}=\frac{\sigma_{\mathrm{f}}^{\prime}-\sigma_{m}}{E}\left(2 \mathrm{~N}_{\mathrm{f}}\right)^{\mathrm{b}}+\varepsilon_{\mathrm{f}}^{\prime}\left(2 \mathrm{~N}_{\mathrm{f}}\right)^{\mathrm{c}}
$$

Daha sonra, Manson ve Halford toplam şekil değişim denkleminde, ortalama gerilme etkisini plastik kısma dahil etmek için denklemi aşağıdaki gibi modifiye etmişlerdir [15].

$$
\frac{\Delta \varepsilon}{2}=\frac{\sigma_{\mathrm{f}}^{\prime}-\sigma_{m}}{E}\left(2 \mathrm{~N}_{\mathrm{f}}\right)^{\mathrm{b}}+\varepsilon_{\mathrm{f}}^{\prime}\left(\frac{\sigma_{\mathrm{f}}^{\prime}-\sigma_{m}}{\sigma_{\mathrm{f}}^{\prime}}\right)^{c / b}\left(2 \mathrm{~N}_{\mathrm{f}}\right)^{\mathrm{c}}
$$

Bunun yanında Smith, Watson ve Topper, ortalama gerilme etkisini dikkate alan bir başka denklem öne sürmüştür[12].

$$
\sigma_{\max }\left(\frac{\Delta \varepsilon}{2}\right)=\frac{\left(\sigma_{\mathrm{f}}^{\prime}\right)^{2}}{E}\left(2 \mathrm{~N}_{\mathrm{f}}\right)^{2 \mathrm{~b}}+\sigma_{\mathrm{f}}^{\prime} \varepsilon_{\mathrm{f}}^{\prime}\left(2 \mathrm{~N}_{\mathrm{f}}\right)^{\mathrm{b}+\mathrm{c}}
$$

Böylece hem ortalama gerilmenin hem de şekil değişim genliğinin etkisi denklemde dâhil olmuş olur. $\sigma_{\max }\left(\frac{\Delta \varepsilon}{2}\right)$ bağıntısı aynı zamanda birim şekil değiştirme enerji yoğunluğu olarak ta yorumlanabilir. 
SWT yorulma modelinde hasar[12],

$$
\begin{aligned}
& P_{S W T} \\
& =\sqrt{\sigma_{\mathrm{f}}^{\prime}\left(2 \mathrm{~N}_{\mathrm{f}}\right)^{\mathrm{b}}\left(\frac{\sigma_{\mathrm{f}}^{\prime}}{E}\left(2 \mathrm{~N}_{\mathrm{f}}\right)^{b}+\varepsilon_{f}^{\prime}\left(2 N_{f}\right)^{c}\right) E}
\end{aligned}
$$

şeklinde bulunabilir. Son olarak, denklem (10) ile (12) birlikte alındığında,

$$
P_{S W T}=\sqrt{\sigma_{\max } \varepsilon_{a} E}
$$

eşitliği yazılabilir. Bergmann, bu denkleme bir düzeltme faktörü ekleyip [16],

$$
P_{\text {Berg }}=\sqrt{\left(\sigma_{a}+a_{b} \sigma_{m}\right) \varepsilon_{a} E}
$$

şeklinde bir yorulma hasar modelini sunmuștur. $\mathrm{Bu}$ denklemde $\mathrm{a}_{\mathrm{b}}$, Bergmann ortalama gerilme düzeltme faktörünü gösterir.

\section{Materyal ve Metot}

Calıșma kapsamında incelenen rot bașında, rot başı radyal yatak malzemesi C45R+QT, rot kolunu temsil eden test aparatı malzemesi, 42CrMo4+QT, aksonu temsil eden test aparatı malzemesi 42CrMo4+QT, mafsal mili malzemesi 41Cr4+QT olarak seçilmiștir. 26 adet rot başı üretilmiş ve test edilmiştir. Şekil 1'de araştırma kapsamında üretilen bir rot başı ve aksonu temsil eden test aparatı verilmiştir.

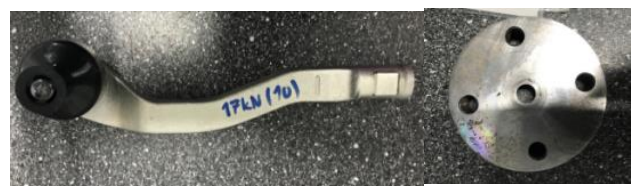

a)

b)

Şekil 1: Test numune örneği, a) rot başı, b) akson

DIN EN10083, DIN EN 10269, EN 10297-1'e göre belirlenen malzeme özellikleri Tablo 1'deki gibidir. Rotu oluşturan rot başı ve rot kolu bilgisayar ortamında tasarlanmıștır. Rot boyu $365.6 \mathrm{~mm}$ olacak șekilde montajı gerçekleştirilmiştir. Rotun HyperMesh programında mesh (ağ modeli) oluşturulmuş ve sonlu elemanlar yöntemi kullanılarak rotun kinematik noktası $4 \mathrm{~mm}$ kalıcı yer değişimine uğratılmıştır. Çözücü olarak ABAQUS paket programı kullanılmıştır. Araç sürücüsü, bu tasarım için $4 \mathrm{~mm}$ 'den fazla değișimi, araç stabilitesi bozulduğu için hissedebilmektedir. $\mathrm{Bu}$ nedenle bu değerden küçük deformasyonlar hissedilememektedir ve sürücü aracı kullanmaya devam eder. Dolayısıyla bu durum yorulma açısından önem taşımaktadır. Ön deformasyona uğrayan rot başının ömrü etkilenerek, tahmin edilen ömürden daha düşük bir ömürde kırılabilir. Rot bașının kinematik noktasının $4 \mathrm{~mm}$ kalıcı yer değişimi sonrası rot başında meydana gelen maksimum plastik şekil değişimi bulunmuştur. Test yapılırken, rot kolu yerine test aparatı tasarlanıp kullanılacaktır. Bu nedenle bilgisayar ortamında rot bașı ve rot kolunu temsil eden test aparatının montajı gerçekleştirilip analizi yapılmış ve rot başını aynı plastik şekil değişimine uğratacak kuvvet hesaplanmıştır. $\mathrm{Bu}$ kuvvet rot başına uygulanarak analizi ABAQUS paket programı ile gerçekleștirilmiș, daha sonra bu ön yüklemenin parça üzerine etkisi ve kalıcı gerilmeler incelenmiştir. Ön yüklemeye uğrayan rot başı daha sonra LMS Virtual.Lab programı kullanılarak yorulma analizleri gerçekleştirilmiştir. Aynı zamanda ön yüklemeye uğramamış rot başı tasarımının da yorulma analizi bu program ile analiz edilmiş ve daha sonra ön yükleme uygulanmış rot başı sonuçları ile karșılaștırılmıștır.

Deneysel olarak, rot başı öncelikle ön yüklemeye uğramadan yorulma testine tabi tutulmuş ve sonuçlar incelenmiştir. Daha sonra ön yüklemeye maruz kalan rot başlarına yorulma testi uygulanarak sonuçlar karşılaştırılmıştır.

Son olarak, bütün elde edilen bulgular dikkate alınarak test sonuçları ile nümerik sonuçlar kıyaslanmış ve farklı yorulma modelleri ile nümerik sonuçlar elde edilerek gerçek durum ile elde edilen sonuçlar karşılaştırılıp bir sonlu elemanlar çözümü için gerekli adımlar oluşturulmuş ve en uygun tasarım için yorulma modeli seçilmiştir.

\subsection{Statik ön yüklemenin belirlenmesi}

İncelenen rot bașında, rot bașı kinematik noktası $4 \mathrm{~mm}$ 'den fazla kalıcı yer değişimine uğradığında sürücü sürüș stabilitesinden rot başında bir problem meydana geldiğini hissedebilmektedir. $\mathrm{Bu}$ değerden daha az deformasyonlarda ise rot bașındaki sorunu fark edemeyip sürüsse devam edebilmektedir. $\mathrm{Bu}$ nedenle öncelikle rot bașı ile rot kolu, rot boyu 
DEÜ FMD 23(68), 647-659, 2021

$365.6 \mathrm{~mm}$ olacak sekilde birbirine bilgisayar ortamında monte edilmiştir. HyperMesh programı kullanılarak hazırlanan sonlu elemanlar modelinde üç boyutlu eleman tipi olarak C3D10 tetra elemanlar kullanılmış ve yüzey gerilmelerini daha iyi hesaplayabilmek için üçgen membran eleman M3D3 kullanılmıştır. Rot geometrisi karmaşık bir geometri olduğundan zaman kazanılması açısından üçgen elemanlar tercih edilmiştir. Hasar rot başında radyal yatak (gövde) üzerinde meydana geldiği için mafsal mili ve plastik yatak analizde ihmal edilmiştir. Rot başı ve rot kolu kinematik noktası için iki rijit eleman tanımlanmıştır. Sınır koşulları ve kuvvetler bu elemanların merkez noktasina uygulanmaktadır. Eleman tipi COUP_KIN olarak seçilmiştir. Şekil 2'de görülen sınır koşulları rot üzerine uygulanmıștır. Burada rot bașının $\mathrm{x}$ ve $\mathrm{z}$ yönündeki ilerlemeleri, rot kolunun ise $\mathrm{x}, \mathrm{y}, \mathrm{z}$ yönlerindeki ilerlemesi ve y ekseninde dönmesi kısıtlanmış durumdadır. Rot başı ile rot kolu ve somun ile diğer parçalar birbirine "tie" (yapışık) temas ile bağlanmıștır. Rot bașı kinematik noktasını $4 \mathrm{~mm}$ yer kalıcı deformasyona uğratacak olan yer değiştirme miktarı $6.79 \mathrm{~mm}$ olarak bulunup rot üzerine uygulanmıștır. Çözücü olarak ABAQUS programı kullanılmıştır.

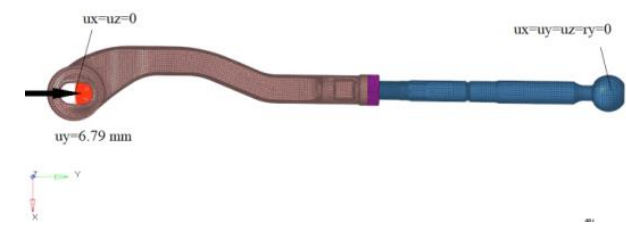

Şekil 2. Rotun sınır şartlarının gösterimi.

Şekil 3'te rota $6.79 \mathrm{~mm}$ +y yönünde yer değiștirme uygulanmıș ve yük kaldırıldığında 4 mm yer değişimi rot başı kinematik noktasında kalıcı olarak elde edilmiştir. $\mathrm{Bu}$ analizin sonunda rot başında meydana gelen plastik deformasyon Şekil 4'de gösterilmiștir.
Tablo 1. Üretilen rotbaşı ve test

\begin{tabular}{|c|c|c|c|}
\hline Malzeme & $\begin{array}{l}\text { Akma } \\
\text { gerilmesi } \\
\left(\sigma_{\mathrm{a}}\right) \\
(\mathrm{min})\end{array}$ & $\begin{array}{l}\text { Çekme } \\
\text { gerilmesi } \\
\left(\sigma_{\mathrm{u}}\right) \\
(\mathrm{MPa}) \\
\end{array}$ & $\begin{array}{l}\text { Kopma } \\
\text { uzaması } \\
(\%)\end{array}$ \\
\hline $\mathrm{C} 45 \mathrm{R}+\mathrm{QT}$ & 490 & $700-850$ & 14 \\
\hline $\begin{array}{l}\text { 42CrMo4+ } \\
\text { QT }\end{array}$ & 700 & $860-1060$ & 16 \\
\hline $41 \mathrm{Cr} 4+\mathrm{QT}$ & 660 & 900 & 14 \\
\hline
\end{tabular}

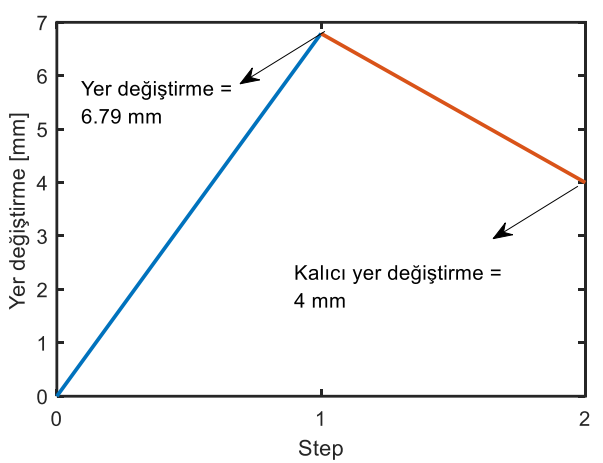

Şekil 3. Rotun yükleme-yük kaldırma eğrisi.

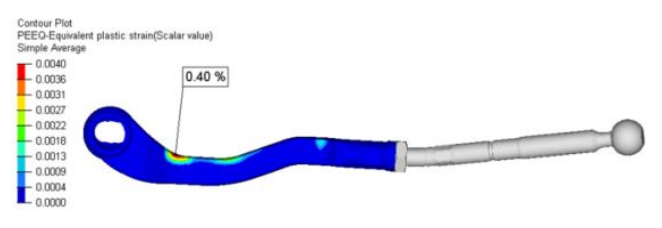

Şekil 4. Rot başı kinematik noktasının $4 \mathrm{~mm}$ kalıcı yer değişimi sonrası rot başında meydana gelen plastik şekil değişimi.

Testlerde rot kolu yerine test aparatı kullanılacağından rot başı ile test aparatının analizi de gerçekleștirilmelidir. $\mathrm{Bu}$ nedenle öncelikle test aparatı ile rot başının montajı bilgisayar ortamında gerçekleştirilmiş, sonlu elemanlar modeli hazırlanmış ve Şekil 4'tek: plastik deformasyonu rot başında meydan getirecek kuvvet hesaplanmıştır. Önceki analizdeki gibi üç boyutlu elemanlar C3D10 tetra eleman ve membran elemanlar M3D3 üçgen eleman olarak kullanılmıştır(Şekil 5). Rot başına +y yönünde kuvvetler uygulanıp kaldırılarak, Şekil 4'teki plastik șekil değișimini sağlayan kuvvet 22739 N olarak bulunmuştur. Rot başına +y yönünde $22739 \mathrm{~N}$ kuvvet uygulanıp kaldırıldığında rot başında \%0.40 
değerinde plastik șekil değișimi olușmaktadır. $\mathrm{Bu}$ șekilde ön yükleme değeri bulunmaktadır. $\mathrm{Bu}$ belirlenen kuvvet testle de rot bașına uygulanacak olan ön deformasyonu sağlayacak olan yüktür.

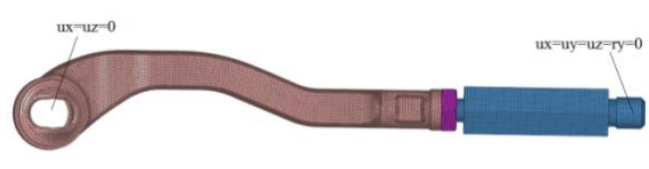

Şekil 5. Rot kolunu temsil eden test aparatı ve rot başı sonlu elemanlar modeli.

\subsection{Deneysel olarak statik ön yüklemenin uygulanması}

Ön yükleme uygulanacak rot başları, rot kolunu temsil eden parçaya takılarak aparatlar aracılığ ile test cihazına monte edilmiștir. Aksonu temsil eden test aparatına mafsal mili monte edilmiştir. Parçaya eksenel olarak +y yönünde bası ön yüklemesi uygulanmıştır. Önceki kısımda belirtildiği gibi bu yükleme değeri 22739 N'dir. Uygulanan kuvvet, rot kolu ve rot başının kinematik noktalarını birleştiren doğru üzerinde uygulanmaktadır. $\mathrm{Bu}$ durumun sağlamak amaciyla, incelenen rot eksenel kaçık olduğundan aksonu temsil eden test aparatı rot için özel üretilmiştir. Test, kuvvet kontrollü olarak yapılmıştır. Sabit üst tablaya rot kolunu temsil eden test aparatı dişli bağlantı ile bağlanmış diğer uçtan rot bașı hareketli alt tablaya aksonu temsil eden test aparatı ile montajı gerçekleştirilmiştir. 12 adet rot başı bu test düzeneği ile ön deformasyona uğratılmıș ve daha sonra uygulanacak olan yorulma testleri için hazır duruma getirilmiștir(Şekil 6).

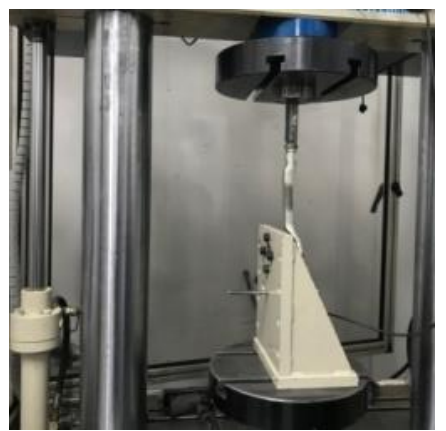

Şekil 6. Rot başına ön yüklemenin uygulanması.

Bir numune için test cihazından alınan ön yükleme kuvvet grafiği Şekil 7'de gösterilmiştir.

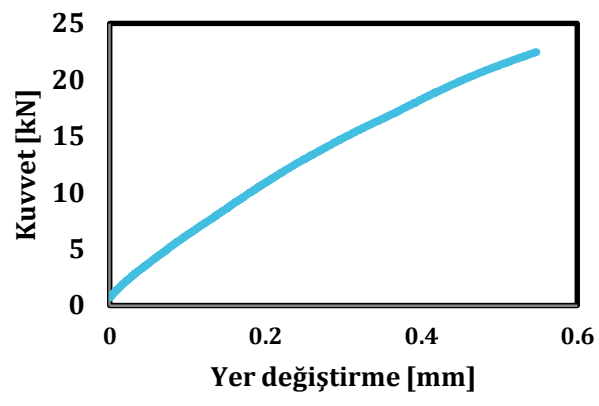

Șekil 7. Test cihazından alınan ön yükleme kuvveti grafiği.

\subsection{Deneysel yorulma testleri}

Yorulma test cihazında (Instron, ABD) hem ön deformasyonlu hem de standart (ön deformasyona uğramamış) parçaların yorulma testi yapılacaktır. Şekil 8'de verildiği üzere hidrolik olarak çalışan cihaz rot başına tekrarlı çeki ve bası kuvvetlerini bir sinüs sinyali biçiminde uygulamaktadır. Direksiyon sisteminden gelebilecek maksimum kuvvet dikkate alınarak belirli bir oranda bir yüksek ve bir düşük kuvvet seçilerek hem düşük çevrimde hem yüksek çevrimde rot başının yorulma davranıșı incelenmiştir. İncelenen rot bașı için testin gerçekleştirileceği yorulma yükleri sirasiyla $\pm 17 \mathrm{kN}, \pm 12 \mathrm{kN}, \pm 10 \mathrm{kN}$ olarak seçilmiştir. Testler bu yükler ile gerçekleştirilip daha sonra Wöhler eğrileri çizilmiştir.

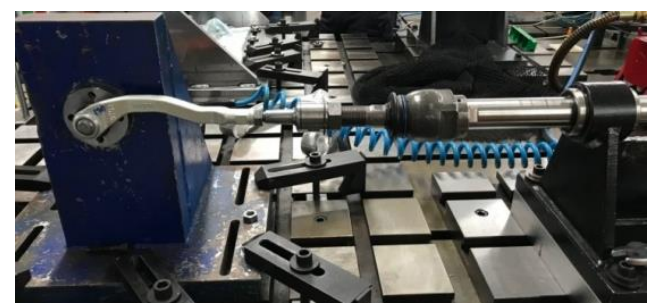

Şekil 8. Rot başı yorulma test düzeneği.

\subsection{Sonlu elemanlar yöntemi ile yorulma} analizleri

Başlangıçta, ön yükleme uygulanarak deforme edilmemiş rot başları yani standart olarak test edilen parçaların sonlu elemanlar modeli oluşturularak yorulma analizi gerçekleştirilmiştir. Rot başı kinematik noktası $\mathrm{x}$ ve $\mathrm{z}$ ilerleme yönlerinden sabitlenmiş, rot kolunu temsil eden parça ise test aparatına bağlanacak bölümünden $\mathrm{x}, \mathrm{y}$ ile $\mathrm{z}$ ilerleme yönlerinde ve y dönme yönünde sabitlenmiştir(Şekil 9). 


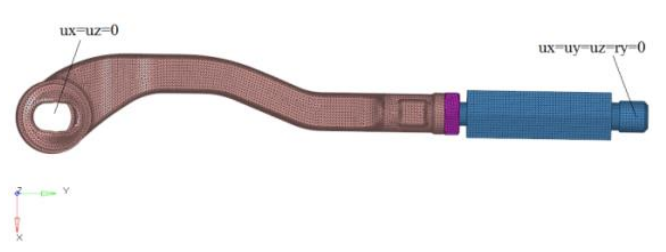

Şekil 9. Rot bașı sonlu elemanlar modeli ve sınır şartları.

Sonlu elemanlar modelinde 36456 M3D3 üçgen eleman, 239668 C3D10 tetra eleman kullanılmıștır. Parçaların bağlantı bölgeleri "tie" (yapışık) olarak tanımlanmıștır. Yorulma analizinin gerçekleștirileceği kuvvetler, test yapılacak olan kuvvetlerle aynı olup sırasıyla $\pm 17 \mathrm{kN}, \pm 12 \mathrm{kN}$, ve $\pm 10 \mathrm{kN}$ olarak seçilmiştir. Her bir kuvvet için ayrı ayrı analizler gerçekleştirilmiştir. Şekil 9'daki sınır koşullarının uygulandığı modelde kuvvet rot başına, önce bası yönünde uygulanmış ve kaldırılmış, daha sonra çeki yönünde uygulanmış ve kaldırılmıştır. Bu şekilde kuvvet bir çevrim olarak parçaya uygulanmıştır(Şekil 10). $\mathrm{Bu}$ model ABAQUS paket programında analiz edilmiştir. Analiz sonuçları LMS Virtual.Lab programına aktarılmış ve yorulma analizi burada gerçekleștirilmiștir. Çözümlemeler test edilen parça malzemelerine uygun olarak, yorulma direnç sabiti of' $=1.5$ $\sigma_{\max }$, yorulma süneklik katsayısı $\varepsilon f^{\prime}=0.59 \Psi$, ve üssel katsayılar olan $b=-0.087$ ve $c=-0.58$ şeklinde seçilerek koşturulmuştur [17]. $\Psi$ ara parametresi, çekme dayanımının elastisite modülüne olan oranını gösterir.

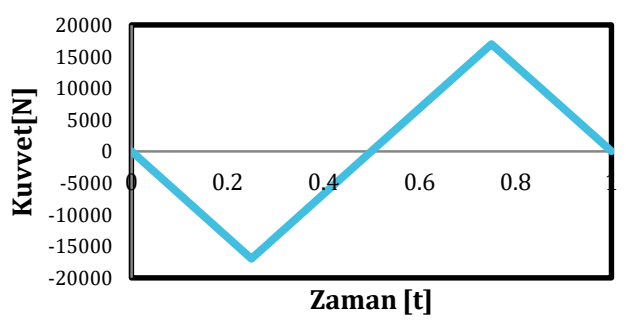

Şekil 10. Rot başına uygulanan bir çevrim $₫ \pm 17$ $\mathrm{kN}$ ) yorulma yükü.

Ön yükleme ile deforme edilmiş rot başlarının yorulma analizi şu şekilde gerçekleştirilmiştir. Öncelikle 22739 N değerindeki ön yükleme, sonlu elemanlar modeline Şekil 11'de gösterildiği gibi uygulanmıștır. Ön yüklemenin sonucu (elemanların gerilme değerleri gibi veriler) *IMPORT komutu kullanılarak yorulma kuvvetinin uygulanacağı analize entegre edilmiştir. $\mathrm{Bu}$ sayede, ön yüklemenin sonucundaki kalıcı gerilmeler hesaba katılarak yorulma analizi gerçekleștirilmiştir.

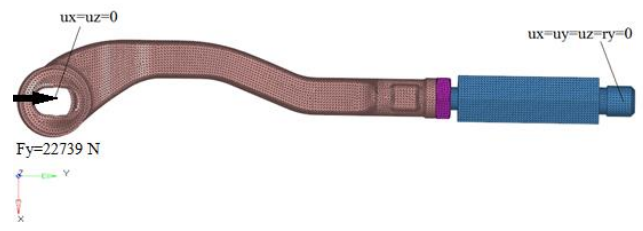

Şekil 11. Ön yükleme adımı sonlu elemanlar modeli

Belirlenmiş olan yorulma kuvveti, rot başına önce bası yönünde uygulanmış ve kaldırılmış, daha sonra çeki yönünde uygulanmış ve kaldırılmıştır. Bu şekilde kuvvet bir çevrim olarak parçaya uygulanmıștır. Parçanın ayrı ayrı $\pm 17 \mathrm{kN}, \pm 12 \mathrm{kN}$, ve $\pm 10 \mathrm{kN}$ yorulma yüklerinde analizi yapılmıștır.

Analizlerde Neuber plastisite düzetme metodu kullanılmıștır. Bergmann, Morrow ve Smith Watson Topper olmak üzere üç farklı yorulma modeli ile rot başındaki hasar incelenmiştir. Sonlu elemanlar analizi ile test sonuçları karşılaştırılmıştır.

\section{Deneysel Yorulma Test Sonuçları}

Toplam 12 adet rot bașına $\pm 17 \mathrm{kN}, \pm 12 \mathrm{kN}$, ve $\pm 10 \mathrm{kN}$ yorulma yükleri uygulanarak testler yapılmıştır. Yorulma test sonuçları, detaylı olarak Tablo 2 'de belirtilmiştir. İlerleyen kısımlarda bu sonuçlarından yararlanılarak Wöhler eğrisi çizdirilmiştir. Bu Wöhler eğrisi kullanılarak farklı yükler altında parçanın ömrü tahmin edilebilir. İki farklı durum için, $12 \mathrm{kN}$ yorulma yükü altında kırılan rot başı numuneleri Şekil 12'de gösterilmiştir.

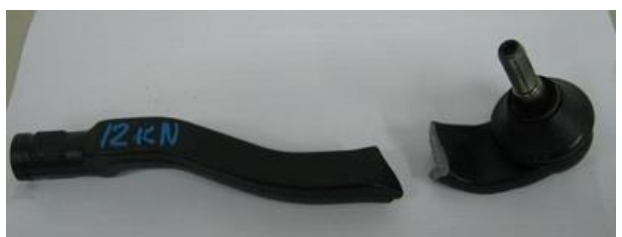

a) 


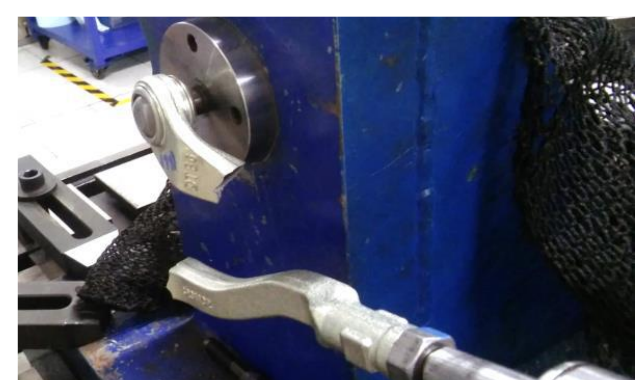

b)

Şekil 12. $\pm 12 \mathrm{kN}$ yorulma yükü altında kırılan rot başı numuneleri. a) ön yükleme ile deforme edilmemiş ( $n=63010)$, b) ön yükleme ile deforme edilmiş $(n=52427)$

Tablo 2. Ön yükleme uygulanmamış ve uygulanmış rot başlarının yorulma testi sonuçları.

\begin{tabular}{llll}
\hline & & \multicolumn{2}{l}{ Çevrim Sayısı ve hasar bölgesi } \\
\cline { 3 - 4 } No & $\begin{array}{l}\text { Uygulanan } \\
\text { Kuvvet[kN] }\end{array}$ & $\begin{array}{l}\text { Önyüklemes } \\
\text { iz }\end{array}$ & Önyüklemeli \\
\hline \multirow{2}{*}{1} & \pm 17 & $8701(\mathrm{RY})$ & $5788(\mathrm{RY})$ \\
2 & \pm 17 & $6718(\mathrm{RY})$ & $5099(\mathrm{RY})$ \\
3 & \pm 17 & $6725(\mathrm{MM})$ & $3741(\mathrm{RY})$ \\
4 & \pm 17 & $7589(\mathrm{RY})$ & $3369(\mathrm{RY})$ \\
5 & \pm 12 & $69102(\mathrm{RY})$ & $3962(\mathrm{RY})$ \\
6 & \pm 12 & $48699(\mathrm{RY})$ & $57697(\mathrm{RY})$ \\
7 & \pm 12 & $60671(\mathrm{RY})$ & $52427(\mathrm{RY})$ \\
8 & \pm 12 & $63010(\mathrm{RY})$ & $41231(\mathrm{RY})$ \\
9 & \pm 10 & $112001(\mathrm{RY})$ & $39871(\mathrm{RY})$ \\
10 & \pm 10 & $275249(\mathrm{RY})$ & $48684(\mathrm{RY})$ \\
11 & \pm 10 & $204110(\mathrm{RY})$ & $236866(\mathrm{RY})$ \\
12 & \pm 10 & $569101(\mathrm{RY})$ & $190383(\mathrm{RY})$ \\
\hline
\end{tabular}

RY radyal yatağı, MM ise mafsal milini temsil eder.

\section{Nümerik Yorulma Analizi Sonuçları}

Bergmann, Morrow ve Smith-Watson-Topper modelleri kullanılarak $\pm 17 \mathrm{kN}, \pm 12 \mathrm{kN}$, ve \pm 10 $\mathrm{kN}$ kuvvetleri ile hem ön yüklemesiz hem de ön yüklemeli yükler uygulanarak sonlu elemanlar analiz yorulma analizleri gerçekleștirilmiştir. Çözüm aşamasında rot başına 22739 N ön yükleme uygulanıp kaldırılmıştır. Ön yüklemenin uygulanıp kaldırılması sonrası parça üzerinde kalan maksimum gerilme dağılımı Şekil 13'de gösterilmiştir. Bunun yanında, $10 \mathrm{kN}$ yorulma yükü kullanılarak hem ön yükleme ile deforme edilmemiş hem de deforme edilmiş rot başlarının gerilme genlikleri (Mises) Şekil 14'te verilmiştir. Maksimum hasar oranının oluştuğu kritik bölgenin yapılan testler sonucunda kırılan bölge ile eşleștiği görülmektedir (Şekil 12 ve Şekil 15). Örneğin ön yüklemesiz için Bergmann yorulma kriteri dikkate alındığında parçaya kırılana kadar uygulanabilecek çevrim sayısı (1/D) bağıntısından 95238 çevrim olarak bulunmuştur(Şekil 15). Geri kalan $\pm 12 \mathrm{kN}$, ve $\pm 17 \mathrm{kN}$ kuvvetlerinde 3 farklı yorulma modeli için nümerik yöntem koșturulup elde edilen nihai sonuçlar bir sonraki başlıkta detaylı olarak verilmiștir.

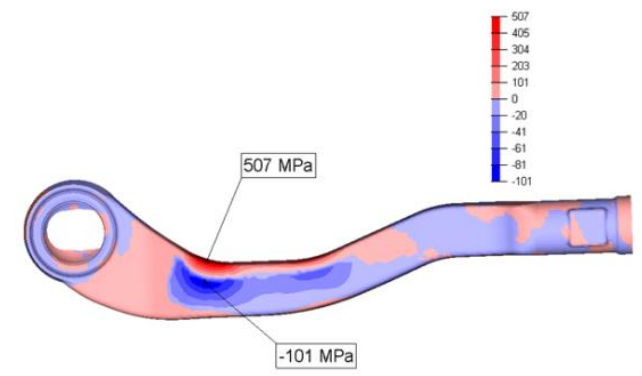

Şekil 13. Ön yükleme uygulanıp kaldırılması sonrası parça üzerinde kalan gerilmeler. (Yönlü VonMises)

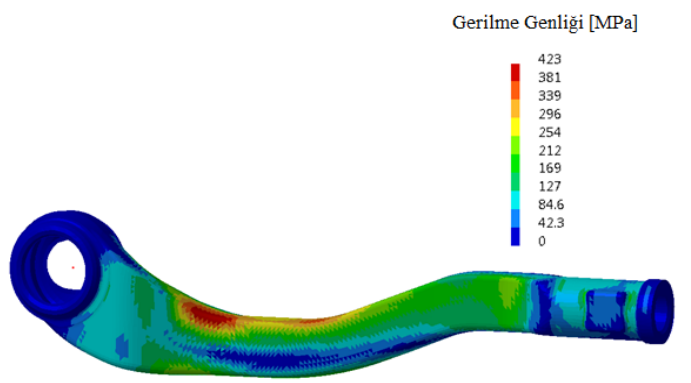

Şekil 14. $\pm 10 \mathrm{kN}$ yorulma yükü kullanılarak analiz edilmiş rot başının gerilme genlik değerleri. 


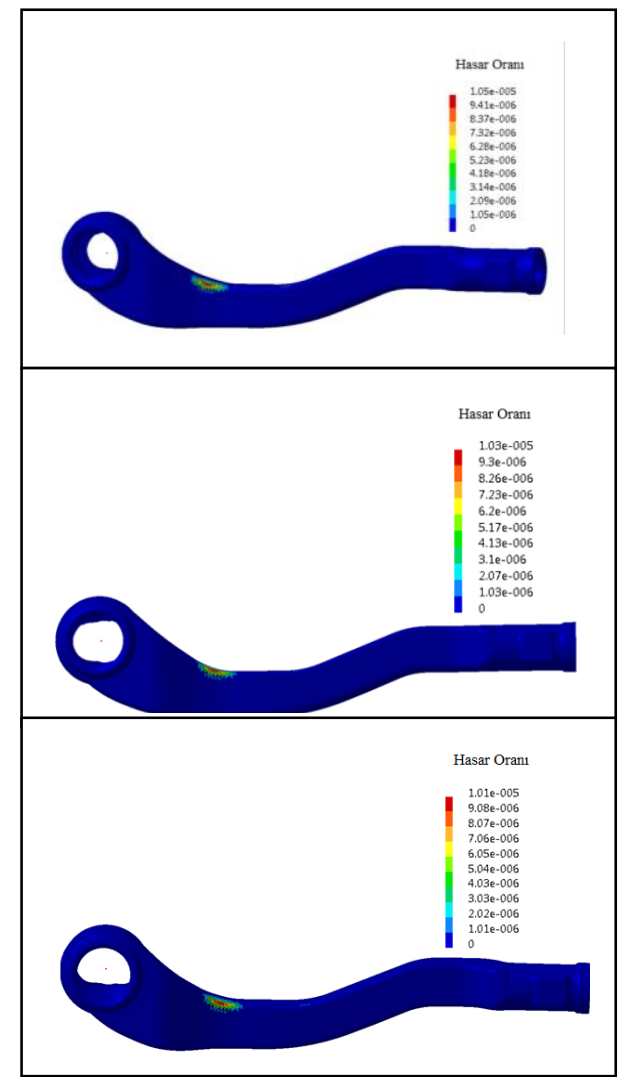

a)

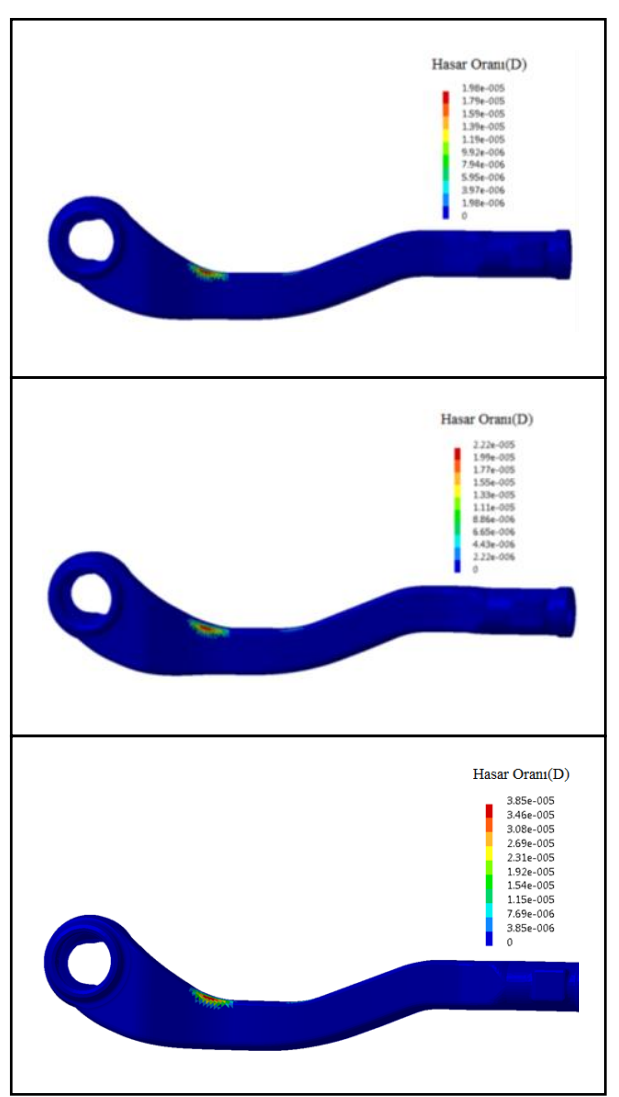

Şekil 15. Farklı yorulma modellerinde, 1 çevrimde $\pm 10 \mathrm{kN}$ yorulma yükü için elde edilen hasar dağılımı. a) ön yükleme ile deforme edilmemiş, b) Ön yükleme ile deforme edilmiş

\section{Sonuç ve Öneriler}

Ön yükleme uygulanmıș rot başı yorulma test sonucu ile ön yükleme uygulanmamış rot başı yorulma test sonucu Şekil 16'da Wöhler eğrisi çizdirilerek karşılaştırılmıştır.

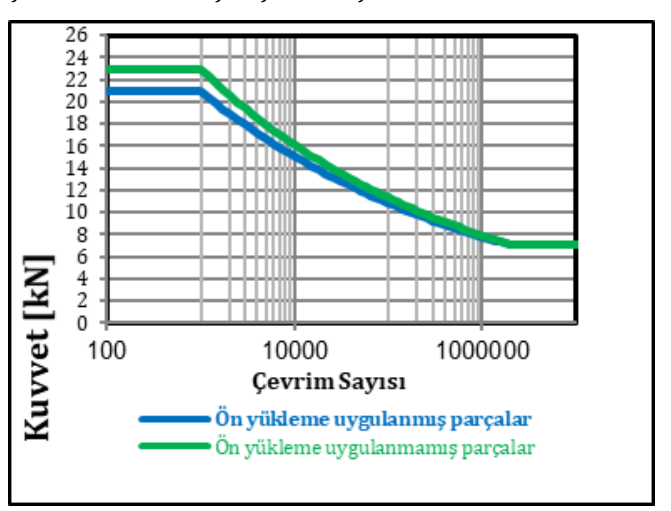

Şekil 16. Wöhler eğrileri ile karşılaştırma
Rot başı çalışma koşullarında birçok yüke maruz kalmaktadır. Bu yükler altında plastik deformasyona uğrayabilmektedir; ancak yorulma ömrü daha çok bu durum ihmal edilerek test ve analiz edilmektedir. Şekil 16 'daki test sonuçlarına bakıldığında plastik deformasyona neden olan bir ön yüklemenin rot başının ömrünü olumsuz etkilediği görülmektedir. Test sonuçları göstermiştir ki rot başının ön yükleme ile deformasyona uğramış olması ömrünü etkilemektedir ve bu nedenle bu durum dikkate alınarak tasarım ve analiz yapılmalıdır. Tablo 3 'te ön yükleme ile deformasyona uğramamış standart rot başı sonlu elemanlar analiz sonuçları gösterilmiştir. 
Tablo 3. Ön yükleme uygulanmamıș ve uygulanmış rot bașı sonlu elemanlar analiz sonuçları.

\begin{tabular}{|c|c|c|c|c|}
\hline \multirow{2}{*}{$\begin{array}{l}\text { Yük } \\
{[\mathrm{kN}]}\end{array}$} & \multirow{2}{*}{$\begin{array}{l}\text { Yorulma } \\
\text { modeli }\end{array}$} & \multicolumn{2}{|c|}{ Çevrim Sayısı } & \multirow{2}{*}{$\begin{array}{l}\text { Çevrim Sayısı } \\
\text { Düşüşü[\%] }\end{array}$} \\
\hline & & $\begin{array}{l}\text { Önyükle } \\
\text { mesiz }\end{array}$ & $\begin{array}{l}\text { Önyükle } \\
\text { meli }\end{array}$ & \\
\hline \multirow{3}{*}{ \pm 10} & Bergmann & 95238 & 50505 & 46,97 \\
\hline & Morrow & 97087 & 45045 & 53,60 \\
\hline & SWT & 99009 & 25974 & 73,77 \\
\hline \multirow{3}{*}{ \pm 12} & Bergmann & 27472 & 17301 & 37,02 \\
\hline & Morrow & 27700 & 16891 & 39,02 \\
\hline & SWT & 28328 & 10964 & 61,3 \\
\hline \multirow{3}{*}{ \pm 17} & Bergmann & 3759 & 2881 & 23,36 \\
\hline & Morrow & 3759 & 3048 & 18,91 \\
\hline & SWT & 3861 & 2123 & 45,01 \\
\hline
\end{tabular}

Üç yorulma modelinin de verdiği sonuçlar birbiriyle tutarlı ve yakındır. Tabloda görüldüğü üzere her yorulma yükü durumunda en kritik sonucu Bergmann vermiștir. Ön yükleme uygulanarak deforme edilmiş parçalarda ise en kritik sonucu Smith-Watson-Topper vermektedir. Ön yükleme ile deforme edilmemiş rot başının yorulma ömür sonuçlarında farklı modeller yakın sonuçlar vermișken, ön yükleme uygulanarak deforme edilmiş rot bașlarının yorulma ömür sonuçlarında farklı modeller birbirinden daha uzak sonuçlar vermiștir. SWT yorulma modeli ön deformasyonun etkisini ömür sonuçlarına çok daha fazla yansıtmıștır. Seçilen $\pm 10 \mathrm{kN}, \pm 12 \mathrm{kN}$ ve $\pm 17 \mathrm{kN}$ yorulma yüklerinde rot başının hem düşük çevrim yorulma davranışı hem de yüksek çevrim yorulma davranışı incelenebilmiştir. Yüksek çevrimlerdeki yüzde düşüş oranı, düşük çevrime göre daha fazla bulunmuştur. $\mathrm{Bu}$ nedenle ön gerilme ile deformasyona uğratılmış rot bașı ömrünün yüksek çevrim sayılarında daha kritik bir yere sahip olduğu düşünülmüştür. Yapılan testler ile hesaplanan sonlu elemanlar analiz sonuçları rot bașının çevrim sayısı düşüşü ve hasar bölgesini belirlemede tutarlıdır. Ön yüklemeye uğramıș rot bașlarının yorulma testi sonrası kırılmış gösterimleri Şekil 17'de ve yine ön yüklemeye uğramış bir rot başının test sonrası hasar bölgesi Şekil 18'de verilmiștir. Burada, sonlu elemanlar analizi sonucundaki kritik bölge ile yorulma testlerindeki kırılma bölgesi konumu eşleşmektedir. Bir başka deyişle, çatlağın başladığı bölge ile sonlu elemanlar analizi sonucu kritik bulunan bölge birbiri ile uyumludur (Şekil 17 ve Şekil 19).

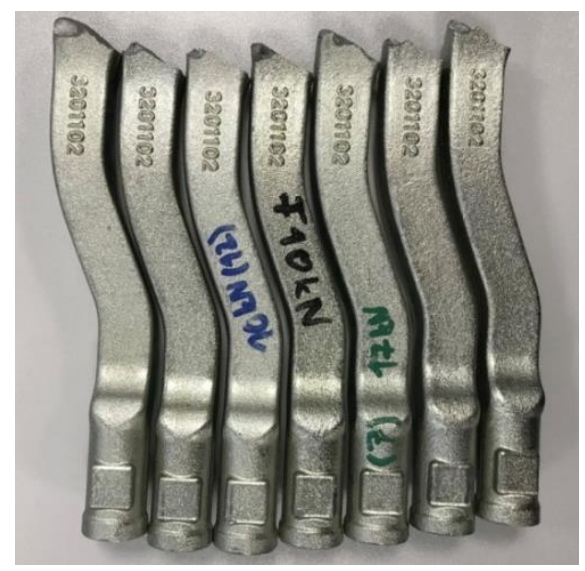

Şekil 17. Ön yüklemeye uğramış rot başlarının yorulma testi sonrası kırılmış gösterimi.

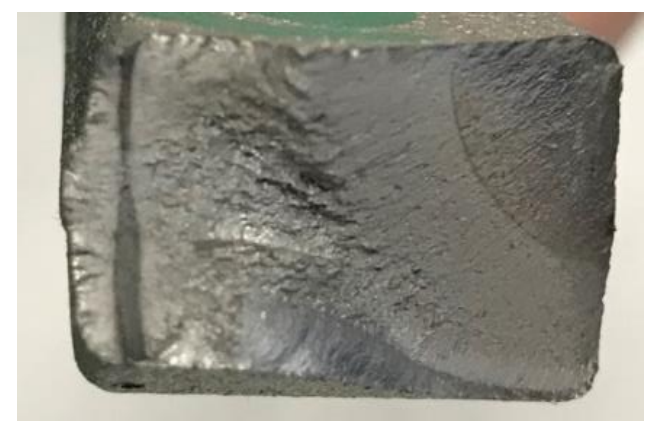

Şekil 18. Ön yüklemeye uğramış rot başının $\pm 10 \mathrm{kN}$ yük altında yorulma testi sonrası kırılma kesiti.

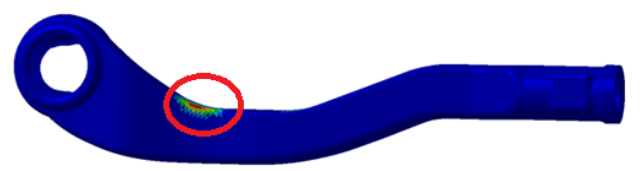

Şekil 19. Ön yüklemeye uğramış rot başının $\pm 10 \mathrm{kN}$ yük altında yorulma analizi hasar bölgesi. 
Șekil 20'deki grafik incelendiğinde görülmüștür ki ön yükleme ile deformasyona uğramamıș (standart) rot başı analiz sonuçlarında üç yorulma modelinin de verdiği sonuçlar birbiriyle yakındır.

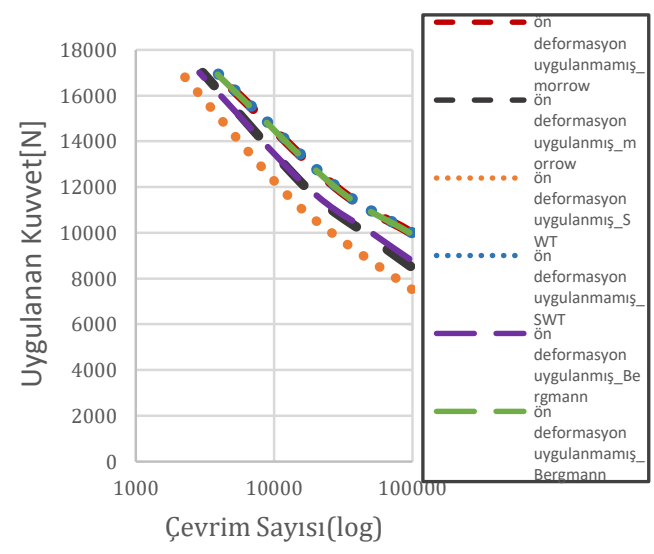

Sekil 20. Farklı yorulma modellerinin karşılaştırılması.

Şekil 21'de görüldüğü üzere, ön deformasyon uygulanmamış parçalarda; her üç parametre de birbirine yakın ve teste göre daha kritik sonuçlar vermiştir.

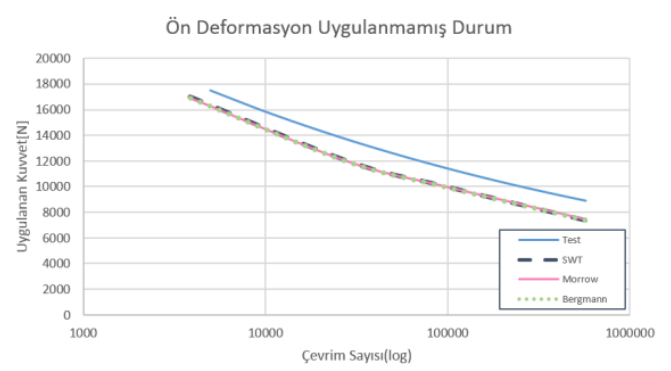

Şekil 21. Ön deformasyon uygulanmamıș rotlarda test ve yorulma modeli sonuçlarının karşılaştırılması.

Şekil 22 için gösterilen ön deformasyon uygulanmış parçalarda;

Bergmann ve Morrow modelleri birbirine ve teste daha yakın sonuç verirken SWT ise ön deformasyon etkisini çok yansıtarak testten daha uzak sonuç vermiştir.

Düşük çevrimlerde test ve analiz sonuçları birbirine daha yakın ve tutarlı bulunmuştur.

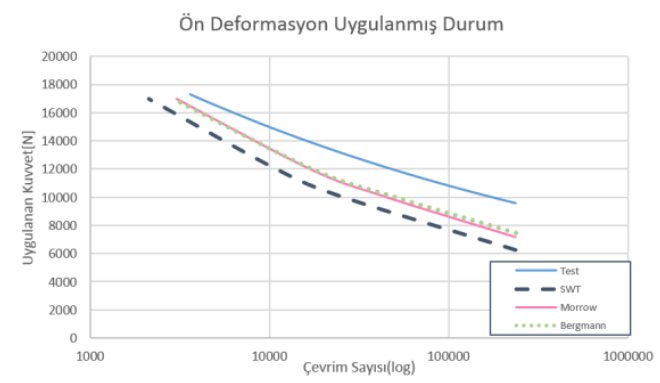

Şekil 22. Ön deformasyon uygulanmış rotlarda test ve yorulma modelleri sonuçlarının karşılaştırılması.

Araştırma kapsamında, ön deformasyon uygulanmış ve uygulanmamış olan rot başları numerik ve deneysel olarak karşılaştırılmıştır. Ön yükleme uygulanmıș rot bașları için sonlu elemanlar analiz basamakları oluşturulmuş ve farklı yorulma modelleri karşılaștırılmıştır. Test ve analiz sonuçlarına bakıldığında plastik deformasyona neden olan bir ön yüklemenin rot bașının ömrünü olumsuz etkilediği açıçca görülmektedir. Rot başının çalışması esnasında taşıdığı kuvvetler dikkate alınmalı, parça üzerinde plastik deformasyon oluşturup oluşturmadığı incelenmeli ve ön deformasyon hesaba katılarak yorulma ömrü tahmin edilmelidir. Sonlu elemanlar yöntemi ile rot başının uğrayabileceği ön deformasyon yorulma ömür tahmini analizine katılarak daha kritik sonuçlar elde edilebilir. Bu nedenle rot başının kullanım esnasındaki deformasyonları dikkate alınarak tasarımı yapılmalı ve analizi gerçekleștirilmelidir. Sonuç olarak, bu çalışmada uyguladığımız deneysel ve nümerik tekniklerle, rot başının ön yükleme ile deformasyona uğramıș olması durumunda ömrünün nasıl etkilendiği tespit edilmiş ve bunun tasarım- analiz çalışmalarında efektif bir şekilde kullanılabileceği görülmüștür.

\section{Teşekkür}

Yazarlar, deneysel testlerde desteklerini aldıkları ZF Lemförder Aks Mod. A.Ş.'den Batuhan Yılmaz'a teşekkür eder.

\section{Kaynaklar}

[1] Bannantine, AJ., Comer, JJ. and Handrock LJ. 1983. Fundamentals of Metal Fatigue Analysis. Englewood Cliffs, Prentice Hall, N.J, USA.

[2] Seçkin, SM. 2010. Plaka Bağlantı Cıvatalarının Yorulmasının Deneysel İncelenmesi. İstanbul Teknik Üniversitesi, Fen Bilimleri Enstitüsü, Yüksek Lisans Tezi, İstanbul. 
DEÜ FMD 23(68), 647-659, 2021

[3] Falah, AH., Alfares, MA., Elkholy, AH. 2007. Failure İnvestigation of a Tie Rod End Of An Automobile Steering System. Engineering Failure Analysis, Cilt. 14, s. 895-902, DOI:10.1016/j.engfailanal.2006.11.045.

[4] Ikechukwu, O., Aniekan, I., Ebunilo, P.O., Ikpe E. 2016. Investigation of a Vehicle Tie Rod Failure in Relation to The Forces Acting On The Suspension System. American Journal of Engineering Research cilt. 5(5), s. 208-217.

[5] Güvenç M. A. 2015. Dayanıklık ve Ömür Kriterlerine Göre Optimum Tasarıma Sahip Süspansiyon ve Direksiyon Sistemi Bileșenleri Geliștirilmesi. Selçuk Üniversitesi, Fen Bilimleri Enstitüsü, Yüksek Lisans Tezi, Konya.

[6] Koh, SK. 2009. Failure analysis of an automotive steering link, Engineering Failure Analysis, Cilt. 16 s. 914-922. DOI: 10.1016/j.engfailanal.2008.08.014.

[7] Budak I. 2019. Plastik Sekil Değișimine Uğramıs Binek Araç Rotunun Yorulma Davranışının Deneysel ve Nümerik Analizi. Ege Üniversitesi, Fen Bilimleri Enstitüsü, Yüksek Lisans Tezi, İzmir.

[8] Sayyar, M., Soroushian, P., Weerasiri RR., 2014 Evaluation of the Prestressing Effects On The Fatigue Life Of Composite Box Sections. Journal of Composite Materials, Cilt. 48(1), s. 71-79, DOI: $10.1177 / 0021998312468187$.

[9] Minguillón, CC., Casas, JR. 1998. Fatigue Reliability Analysis of Prestressed Concrete Bridges. Journal of Structural Engineering, Cilt. 124(12), s. 1458-1466.

[10] Jeong, Y., Kim, W, Gribniak V., Hui, D. 2019. Fatigue Behavior of Concrete Beams Prestressed with Partially Bonded CFRP Bars Subjected to Cyclic Loads. Materials, Cilt. 12(20), s. 3352. DOI: 10.3390/ma12203352.

[11] Morrow, J. Fatigue Properties of Metals, 1968. Section 3.2. In: Fatigue Design Handbook, Pub. No. AE-4. SAE, Warrendale, PA, USA

[12] Smith, KN., Watson, P., Topper, TH. 1970. A StressStrain Function For The Fatigue of Materials. Journal of Materials, Cilt. 5, s. 767-778.

[13] Basquin, OH. 1910. The Exponential Law of Endurance Tests. American Society for Testing and Materials. 10, 625-630.

[14] Socie, DF., Morrow, JD. 1980. Review of Contemporary Approaches to Fatigue Damage Analysis. Editors: BurkeJJ, WeissV.Riskand Failure Analysis for Improved Performance and Reliability, s. 141-194, Plenum Publication Corp, NY, USA.

[15] Manson, SS., Halford GR. 1981. Practical Implementation of The Double Linear Damage Rule and Damage curve Approach For Treating Cumulative Fatigue Damage. International Journal of Fracture, Cilt. 17,s. 169-172.

[16] Bergmann JW. $1983 . \quad$ Zur Betriebsfestigkeitsbemessung gekerbter Bauteile aufder Grundlage der 'örtlichen Beanspruchungen, Institut f'ür Stahlbau und Werk-stoffmechanik, TH Darmstadt.

[17] LMS user help. 2017. UML Estimation of Fatigue Properties. Anonim, 1995. 